\title{
Rehun muurahaishappo- ja bentsoehappolisäysten vaikutukset lihasioilla
}

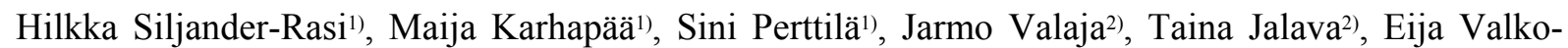
nen $^{2}$, Eija Venäläinen ${ }^{2)}$ ja Hsin-Yi Chen ${ }^{3)}$

${ }^{1)}$ MTT Sikatalous, Tervamäentie 179, 05840 Hyvinkää, hilkka.siljander-rasi@mtt.fi

${ }^{2}$ MTT Eläinravitsemus, 31600 Jokioinen, jarmo.valaja@mtt.fi

${ }^{3}$ Kemira, Helsinki

\section{Tiivistelmä}

Rehuun lisätty muurahaishappo on parantanut sikojen kasvua pienillä käyttömäärillä (6-8 g/kg). Haihtuvan ja pistävän hajuisen nestemäisen muurahaishapon käsittelyä helpottamaan on kehitetty ammonoituja happotuotteita. Muurahaishapon tehokkuutta on pyritty parantamaan muilla orgaanisilla hapoilla. Bentsoehappo on kiinnostava, koska kasvua edistävän ja sulavuutta parantavan vaikutuksen lisäksi sen lisäys rehuun on alentanut lietelannan pH:ta. Kun lannan $\mathrm{pH}$ alenee, ammoniakkipäästöt vähenevät ammoniumtypen pidättyessä lantaan.

Tutkimuksessa selvitettiin, kuinka ammonoidun nestemäisen tai kiinteän muurahaishappovalmisteen korvaaminen bentsoehapolla vaikuttaa lihasikojen tuotantotuloksiin, ravintoaineiden kokonaissulavuuteen, typen hyväksikäyttöön ja ammoniakin haihtumiseen lietelannasta.

Tutkimukseen sisältyi sulavuus- ja tasekoe sekä kasvatuskoe. Tasekokeessa oli 8 leikkoa (alkupaino 38,5 kg). Koeruokintoja oli 8 ja koejaksoja 6 (cyclic change-over-koemalli). Kasvatuskokeessa oli 320 lihasikaa (alkupaino 25,2 kg). Karsinoissa oli neljä sikaa, kaksi imisää ja kaksi leikkoa. Molemmissa kokeissa ammonoidun happovalmisteen $(6 \mathrm{~g} / \mathrm{kg}$ nestemäistä tai $12 \mathrm{~g} / \mathrm{kg}$ kiinteää valmistetta) muurahaishaposta korvattiin rehuissa bentsoehapolla 0, 25, 50 tai $100 \%$. Kontrollirehuna oli happoja sisältämätön rehu. Alku- ja loppukasvatusrehut olivat ohra-soijapohjaisia ja rakeistettuja. Sulavuuskokeessa siat saivat alkukasvatusrehuja $85 \mathrm{~g} \mathrm{ka} / \mathrm{kg} \mathrm{W}^{0,75}$. Kasvatuskokeessa siat saivat 1,4-3,2 ry päivässä.

Nestemäisen happovalmisteen korvaaminen bentsoehapolla paransi suoraviivaisesti orgaanisen aineen ja raakavalkuaisen sulavuutta $(\mathrm{p}<0,05)$ ja kiinteän valmisteen korvaaminen bentsoehapolla paransi lisäksi kuiva-aineen, raakarasvan ja raakahiilihydraattien sulavuutta $(\mathrm{P}<0,01)$. Kontrolliruokintaan verrattuna bentsoehappo paransi vain raakahilihydraattien sulavuutta. Näiden ravintoaineiden sulavuus oli parempi nestemäistä kuin kiinteää happovalmistetta käytettäessä. Typen pidättymisessä ei ollut eroja kontrolliruokinnan ja happoja sisältäneiden ruokintojen välillä. Kiinteää happovalmistetta saaneet siat joivat vettä ja erittivät virtsaa enemmän kuin nestemäistä valmistetta saaneet siat $(\mathrm{P}<0,001)$. Bentsoehapolla ei ollut selkeitä vaikutuksia virtsan $\mathrm{pH}$-arvoon. Lietelannan ammoniumtypen määrässä ei havaittu eroa ruokintojen välillä.

Nestemäisen happovalmisteen korvaaminen bentsoehapolla paransi suoraviivaisesti sikojen rehuhyötysuhdetta alkukasvatuksessa $(\mathrm{p}<0,05)$. Bentsoehapon käyttö ei vaikuttanut koko kasvatuskauden tuotantotuloksiin. Happoja sisältäneillä ruokinnoilla sikojen tuotantotulokset eivät poikenneet kontrollirehulla ruokittujen tuloksista, eikä eroja nestemäisen ja kiinteän happovalmisteen välillä havaittu.

Tutkimuksessa ei juuri saavutettu etua muurahaishappovalmisteiden korvaamisesta bentsoehapolla. Kiinteää happovalmistetta käytettäessä huonompi ravintoaineiden sulavuus ja veden juonnin lisäys saattoi johtua kantaja-aineen (piidioksidi) suuresta sidontakyvystä.

Asiasanat: lihasika, muurahaishappo, bentsoehappo, ruokinta, sulavuus, typpi, ammoniakki 


\section{Johdanto}

Rehuun lisätty muurahaishappo on parantanut lihasikojen kasvua ja rehuhyötysuhdetta sekä ravintoaineiden sulavuutta, mm. aminohappojen ohutsuolisulavuutta (Partanen \& Mroz 1999). Muurahaishappo on tehokasta pienemmillä käyttömäärillä (6-8 g/ kg) kuin muut orgaaniset hapot (Partanen 2001). Haihtuvan ja pistävän hajuisen nestemäisen muurahaishapon käsittelyä helpottamaan on kehitetty osittain ammonoituja happotuotteita. Happo voidaan käsittelyn helpottamiseksi myös imeyttää kantaaineeseen, kuten piidioksidiin (silika).

Muurahaishapon tehokkuutta on myös pyritty parantamaan muilla orgaanisilla hapoilla. Bentsoehappo on tässä mielessä kiinnostava, koska sen antimikrobinen vaikutus koli- ja maitohappobakteereihin on ollut in vitro-kokeissa suurempi kuin muurahaishapon (Knarreborg ym. 2002). Bentsoehapon lisäys $(10 \mathrm{~g} / \mathrm{kg})$ rehuun on parantanut sikojen kasvua ja rehuhyötysuhdetta (Van der PeetSchwering ym.1998). Kalsiumbentsoaatin käyttö $(24 \mathrm{~g} / \mathrm{kg})$ on parantanut useiden aminohappojen ohutsuolisulavuutta sekä orgaanisen aineen, tuhkan ja energian kokonaissulavuutta (Mroz ym. 2000). Bentsoehapon tai kalsiumbentsoaatin lisäys rehuun on myös alentanut virtsan ja lietelannan pH:ta. Kun lannan pH alenee, ammoniakkipäästöt vähenevät ammoniumtypen pidättyessä lantaan.

Tässä tutkimuksessa selvitettiin, kuinka ammonoidun nestemäisen tai kiinteän muurahaishappovalmisteen korvaaminen bentsoehapolla vaikuttaa lihasikojen tuotantotuloksiin, ravintoaineiden kokonaissulavuuteen, typen hyväksikäyttöön ja ammoniakin haihtumiseen lietelannasta.

\section{Aineisto ja menetelmät}

Sulavuus- ja tasekokeessa oli kahdeksan leikkosikaa, jotka olivat maatiais- ja yorkshirerodun risteytyksiä. Ne painoivat kokeen alussa 38,5 kg (s.d. 1,85). Ne olivat kokeen ajan yksilökarsinoissa $(1,43 \mathrm{x}$ $1,23 \mathrm{~m}$ ), joiden lattia oli muoviritilää. Koemallina oli 8 x 6 cyclic change-over, jossa oli kahdeksan koerehua ja kuusi koejaksoa. Jakson pituus oli 10 päivää, joista kuusi oli valmistuskautta ja neljänä tehtiin sonnan ja virtsan kokonaiskeruu. Sonta kerättiin sian peräaukon ympärille kiinnitettyyn muovipussiin ja säilytettiin $-20^{\circ} \mathrm{C}$ :ssa. Virtsa kerättiin jäähauteessa pidettyihin pulloihin, jotka tyhjennettiin kahdesti päivässä. Virtsa jaettiin kahteen osanäytteeseen, joista toiseen lisättiin $10 \mathrm{M}$ suolahappoa. Näytteet säilytettiin $-20^{\circ} \mathrm{C}$ :ssa.

Kasvatuskokeessa oli 320 lihasikaa, joista $30 \%$ oli maatiais- tai yorkshirerotuisia, $59 \%$ näiden risteytyksiä ja 11 \% duroc-risteytyksiä. Siat olivat neljän sian karsinoissa, kaksi leikkoa ja kaksi imisää kussakin karsinassa. Karsinat arvottiin kahdeksaan koekäsittelyyn.

Molemmissa kokeissa käytettiin ammonoituja muurahaishappovalmisteita (AMMFOR 99 S 10, Kemira Oyj, Helsinki). Nestemäinen valmiste sisälsi muurahaishappoa 620 g/kg, ammoniumformiaattia $370 \mathrm{~g} / \mathrm{kg}$ ja vettä $10 \mathrm{~g} / \mathrm{kg}$. Kiinteä valmiste sisälsi muurahaishappoa $400 \mathrm{~g} / \mathrm{kg}$, ammoniumformiaattia $240 \mathrm{~g} / \mathrm{kg}$, piidioksidia $350 \mathrm{~g} / \mathrm{kg}$ ja vettä $10 \mathrm{~g} / \mathrm{kg}$. Kaikkiaan nestemäisessä valmisteessa oli muurahaishappoa $880 \mathrm{~g} / \mathrm{kg}$ ja kiinteässä $570 \mathrm{~g} / \mathrm{kg}$. Koerehuja oli kahdeksan. Nestemäistä valmistetta lisättiin rehuun $6 \mathrm{~g} / \mathrm{kg}$ ja kiinteää $12 \mathrm{~g} / \mathrm{kg}$, tavoitteena oli saada rehuihin sama määrä muurahaishappoa. Molempien valmisteiden muurahaishaposta korvattiin bentsoehapolla 25 tai $50 \%$ eli 1,5 tai $3,0 \mathrm{~g} / \mathrm{kg}$. Yhteen koerehuun lisättiin ainoastaan bentsoehappoa $6 \mathrm{~g} / \mathrm{kg}$. Lisäksi kokeessa oli kontrollirehu, johon ei lisätty happoja.

Kontrollirehu sisälsi alku- ja loppukasvatuksessa ohraa 804 ja $883 \mathrm{~g} / \mathrm{kg}$, soijarouhetta 162 ja 87 $\mathrm{g} / \mathrm{kg}$, L-lysiini-hydrokloridia $3,7 \mathrm{ja} 2,9 \mathrm{~g} / \mathrm{kg}$, L-treoniinia $1,0 \mathrm{ja} 0,5 \mathrm{~g} / \mathrm{kg}$, ruokintakalkkia 7,7 ja 7,4 $\mathrm{g} / \mathrm{kg}$ ja monokalsiumfosfaattia 7,3 ja $6,2 \mathrm{~g} / \mathrm{kg}$. Molemmat rehut sisälsivät $13 \mathrm{~g} / \mathrm{kg}$ kivennäisvitamiiniseosta ja alkukasvatusrehu lisäksi $0,7 \mathrm{~g} / \mathrm{kg}$ DL-metioniinia. Happovalmisteilla korvattiin seosten ohraa ja soijarouhetta. Kaikki rehut täyttivät sikojen ravintoaineiden tarvesuositukset (MTT 2004). Seokset rakeistettiin läpimitaltaan $4 \mathrm{~mm}: n$ rakeiksi. Sulavuuskokeessa siat saivat alkukasvatusrehuja $85 \mathrm{~g} \mathrm{ka} / \mathrm{kg} \mathrm{W}^{0,75}$. Kasvatuskokeessa siat saivat 1,4-3,2 ry päivässä. Alkukasvatusrehua annettiin 33 päivän ajan. Siat ruokittiin kahdesti päivässä ja rehut kostutettiin vedellä (vesi:rehu 1-2:1).

Kasvatuskokeen siat lähetettiin teuraaksi keskimäärin 110,3 kg:n (s.d. 1,41) painoisina. Teurastamolla ruhoista mitattiin lihaprosentin määrittämiseksi Hennessy GP-laitteella kylkisilavan paksuus 8 $\mathrm{cm}$ ruhon keskiviivasta viimeisen kylkiluun takaa $(\mathrm{S} 1)$ ja $6 \mathrm{~cm}$ ruhon keskiviivasta 3. ja 4. kylkiluun välistä (S2) sekä ulkofileen paksuus samasta kohdasta kuin S2 (lihasmitta).

Sulavuuskokeessa mitattiin virtsan $\mathrm{pH}$ kahdesti päivässä. Kullakin jaksolla ammoniumtypen haihtumista mitattiin epäsuorasti huoneenlämmössä säilytetystä virtsan ja sonnan seoksesta, josta otet- 
tiin näytteet $0,1,2,3,6$ ja 24 tunnin kuluttua ja määritettiin urea ja ammoniumtyppi. Kasvatuskokeen rehuista määritettiin kuiva-aine kerran kuukaudessa $\left(103{ }^{\circ} \mathrm{C}, 16 \mathrm{~h}\right)$. Sulavuus- ja kasvatuskokeen rehut analysoitiin erikseen MTT:n eläinravitsemuksen laboratoriossa. Bentsoehappo määritettiin nestekromatografisesti Kuopion kaupungin elintarvikelaboratoriossa (Nordic Committee on Food Analysis 1997).

Aineistot analysoitiin tilastollisesti SAS-ohjelmistolla. Sulavuus- ja tasekokeen (6 havaintoa/käsittely) mallissa olivat koekäsittelyn, jakson ja eläimen vaikutukset. Kasvatuskokeessa havaintoyksikkönä oli karsina (10 havaintoa/käsittely) ja mallissa koekäsittelyn vaikutus. Muurahaishappovalmisteiden korvaamista bentsoehapolla tarkasteltiin polynomikontrastein (korvauksen suoraviivainen sekä 2. ja 3. asteen käyräviivainen vaikutus). Kontrastin avulla verrattiin myös nestemäisen ja kiinteän muurahaishappovalmisteen vaikutuksia. Koekäsittelyjä verrattiin pareittain kontrollikäsittelyyn Dunnettin testillä.

\section{Tulokset ja tulosten tarkastelu Rehujen kemiallinen koostumus}

Alkukasvatusrehujen raakavalkuais- ja lysiinipitoisuus vaihteli enemmän kuin loppukasvatusrehujen. Kiinteää muurahaishappovalmistetta sisältäneiden rehujen muurahaishappopitoisuus oli suurempi kuin nestemäistä muurahaishappovalmistetta sisältäneiden. Systemaattisen eron syynä on todennäköisesti, että kiinteän valmisteen muurahaishapon määrä arvioitiin liian pieneksi. Bentsoehapon lisäykset olivat suunnitellun mukaiset (Taulukko 1). Sekä nestemäisen että kiinteän muurahaishappovalmisteen lisäys laski rehun pH:ta keskimäärin 0,7 yksikköä ja pelkän bentsoehapon lisäys keskimäärin 0,4 yksikköä.

Taulukko 1. Koerehujen suunnitellut ja analysoidut muurahaishappo- ja bentsoehappopitoisuudet.

\begin{tabular}{lllllllll}
\hline Rehu & 1 & 2 & 3 & 4 & 5 & 6 & 7 & 8 \\
\cline { 2 - 9 } AMMFOR 99 S 10 (nestemäinen), g/kg & - & 6,0 & 4,5 & 3,0 & - & - & - & - \\
AMMFOR 99 S 10 (kiinteä), g/kg & - & - & - & - & 12,0 & 9,0 & 6,0 & - \\
Bentsoehappo, g/kg & - & - & 1,5 & 3,0 & - & 1,5 & 3,0 & 6,0 \\
\hline Muurahaishappo, g/kg ka & & & & & & & & \\
Alkukasvatusrehu, sulavuuskoe & & 4,2 & 3,4 & 2,4 & 6,3 & 4,9 & 3,4 & \\
Alkukasvatusrehu, kasvatuskoe & & 5,2 & 3,7 & 4,3 & 6,2 & 5,1 & 3,4 & \\
Loppukasvatusrehu, kasvatuskoe & 5,4 & 4,1 & 2,8 & 6,7 & 5,0 & 3,5 & \\
Bentsoehappo, g/kg ka & & & & & & & \\
Alkukasvatusrehu, sulavuuskoe & & & 1,7 & 3,1 & & 1,4 & 2,7 & 6,4 \\
Alkukasvatusrehu, kasvatuskoe & & & 1,8 & 3,2 & & 1,4 & 2,8 & 6,7 \\
Loppukasvatusrehu, kasvatuskoe & & & 1,7 & 3,3 & & 1,5 & 3,0 & 6,2 \\
\hline
\end{tabular}

\section{Sulavuus- ja tasekoe}

Nestemäisen muurahaishappovalmisteen korvaus bentsoehapolla paransi orgaanisen aineen ja raakavalkuaisen kokonaissulavuutta ( $<<0,05$, taulukko 2 ). Kiinteän muurahaishappotuotteen korvaaminen bentsoehapolla paransi näiden lisäksi kuiva-aineen $(p<0,001)$, raakarasvan $(p<0,01)$ ja raakahiilihydraattien $(p<0,001)$ sulavuutta. Kontrolliruokintaan verrattuna raakahiilihydraattien sulavuus parani korvattaessa nestemäisen muurahaishappovalmisteen haposta 25 tai $50 \%$ bentsoehapolla tai lisättäessä rehuun ainoastaan bentsoehappoa $(\mathrm{p}<0,05)$. Happoja sisältäneiden rehujen muiden ravintoaineiden sulavuus ei poikennut kontrollirehusta. Mroz ym. (2000) havaitsivat kalsiumbentsoaatin $(24 \mathrm{~g} / \mathrm{kg}$ ) parantavan kuiva-aineen, energian ja tuhkan sulavuutta. Muissa tutkimuksissa myös muurahaishappo on parantanut ravintoaineiden sulavuutta (Partanen 2001).

Kuiva-aineen, orgaanisen aineen, raakavalkuaisen, raakarasvan ja raakahiilihydraattien sulavuus oli kiinteää happotuotetta käytettäessä huonompi kuin nestemäistä happotuotetta käytettäessä $(\mathrm{p}<0,001)$. Tässä kokeessa hapon kantaja-aineena käytetyn piidioksidin on myös aikaisemmin havaittu huonontavan ravintoaineiden sulavuutta (Mosenthin ym. 1992). Huokoinen piidioksidi saattaa pidättää itseensä ravintoaineita ja siten estää niiden imeytymisen.

Rehun bentsoehappolisäyksillä ei ollut selkeitä vaikutuksia sikojen typen hyväksikäyttöön. Typpeä pidättyi sikoihin enemmän käytettäessä kiinteää kuin nestemäistä happovalmistetta $(p<0,05)$. Happoja sisältäneitä rehuja saaneiden sikojen typen hyväksikäyttö ei kuitenkaan poikennut kontrolliryhmän tuloksista. Osa typen hyväksikäytön eroista saattoi myös johtua rehun valkuaispitoisuuden vaihtelusta. 
Kiinteää happovalmistetta saaneet siat joivat enemmän vettä $(\mathrm{p}<0,001)$ ja erittivät virtsaa $(\mathrm{p}<0,001)$ kuin nestemäistä happovalmistetta saaneet siat. Syynä saattoi olla piidioksidin suuri vedensidontakyky. Virtsan määrän lisääntyminen ei ole käytännössä toivottavaa, koska se lisää lietelannan määrää.

Ammoniakin haihtumista mitattiin epäsuorasti virtsan ja lannan seoksesta. Koekäsittelyt eivät vaikuttaneet urean ja ammoniumtypen määrään seoksessa 24 h:n aikana. Bentsoehapon käytöllä ei ollut selkeää vaikutusta virtsan $\mathrm{pH}$-arvoihin, ja suurimmalla käyttötasolla $(6 \mathrm{~g} / \mathrm{kg}) \mathrm{pH}$ oli sama kuin kontrolliruokinnalla. Aikaisemmissa tutkimuksissa, joissa bentsoehappo on alentanut virtsan $\mathrm{pH}: t a$ ja estänyt ammoniakin haihtumista lietelannasta, hapon käyttömäärät ovat olleet suurempia (Mroz ym. 2000, van der Peet-Schwering ym. 1998). Nestemäistä happotuotetta käytettäessä virtsan pH oli matalampi kuin kiinteää tuotetta käytettäessä $(\mathrm{p}<0,001)$. Kontrolliruokintaan verrattuna virtsan $\mathrm{pH}$ oli matalampi ainoastaan, kun nestemäisestä muurahaishaposta korvattiin $50 \%$ bentsoehapolla.

\section{Kasvatuskoe}

Sikojen terveys ja ruokahalu olivat kokeen aikana hyvät. Ne kasvoivat keskimäärin $978 \mathrm{~g}$ (s.d. 44,7) päivässä. Alkukasvatuksessa, joka kesti 33 päivää, parani sikojen rehuhyötysuhde $(\mathrm{p}<0,05)$ ja päiväkasvu $(\mathrm{p}=0,07)$ suoraviivaisesti korvattaessa nestemäistä muurahaishappovalmistetta bentsoehapolla. Loppukasvatuksessa tai koko kasvatuskaudella bentsoehapon lisäykset eivät vaikuttaneet sikojen tuotantotuloksiin. Happoja sisältäneitä rehuja saaneiden sikojen kasvu- ja rehunkäyttö ei myöskään poikennut kontrolliryhmän tuloksista missään kasvatuksen vaiheessa.

Kiinteän ja nestemäisen muurahaishappovalmisteen vaikutus sikojen tuotantotuloksiin oli samanlainen alkukasvatuksen aikana. Loppukasvatuksessa kiinteää happovalmistetta saaneet siat kuluttivat enemmän rehun kuiva-ainetta kasvukiloa kohti kuin nestemäistä valmistetta saaneet $(\mathrm{p}<0,05)$, mutta rehuyksiköiden kulutuksessa ero oli pienempi $(\mathrm{p}=0.10)$. Sikojen loppukasvatuksen päiväkasvu oli kuitenkin hiukan huonompi $(\mathrm{p}=0,07)$ kiinteää valmistetta käytettäessä. Syynä eroihin saattoi olla ravintoaineiden huonompi sulavuus kiinteää happotuotetta käytettäessä.

Yhtä pienten bentsoehappomäärien käytöstä kuin tässä kokeessa on vähän tutkimustuloksia. Tilakokeissa bentsoehappolisäys $(5 \mathrm{~g} / \mathrm{kg})$ on parantanut lihasikojen kasvua happoa sisältämättömään rehuun verrattuna, ja alkukasvatuksessa rehuhyötysuhdetta antibioottista rehun lisäainetta sisältäneeseen ruokintaan verrattuna. Kun bentsoehappoa lisättiin $15 \mathrm{~g} / \mathrm{kg}$ rehua, sen käyttö ei vaikuttanut sikojen tuotantotuloksiin (Mellor 2004). Van der Peet-Schweringin ym. (1998) tutkimuksessa bentsoehapon vaikutus lihasikojen kasvuun ja rehuhyötysuhteeseen oli käyräviivainen, ja paras tulos saavutettiin käytettäessä bentsoehappoa $10 \mathrm{~g} / \mathrm{kg}$ rehua.

Aikaisemmissa tutkimuksissa rehun muurahaishappolisäyksistä on ollut suurin hyöty sikojen alkukasvatuksessa (Øverland ym. 2000, Siljander-Rasi ym. 1998). Hyvissä ympäristöolosuhteissa ilman happolisäyksiä ruokitut siat pystyvät kompensoimaan huonomman alkukasvun myöhemmin (SiljanderRasi ym. 1998). Kun hygieniassa on puutteita ja useilta eri tiloilta tulleita sikoja sekoitetaan keskenään, muurahaishapon käytöstä on hyötyä myös loppukasvatuksessa (Partanen ym. 2002). Tämä tutkimus tehtiin yhdistelmäsikalassa melko hyvissä olosuhteissa, eikä happojen käytöstä saatu etuja.

Rehussaan orgaanisia happoja saaneiden sikojen teuraslaatu oli samanlainen kuin kontrollirehulla ruokittujen sikojen. Aikaisemmissakaan tutkimuksissa orgaanisten happojen käyttö ei ole vaikuttanut sikojen teuraslaatuun (Siljander-Rasi ym. 1998, Partanen ym. 2002). Kiinteän happotuotteen korvaaminen bentsoehapolla huononsi sikojen ruhon lihaprosenttia suoraviivaisesti $(\mathrm{P}=0,07)$.

\section{Johtopäätökset}

Tulostemme perusteella muurahaishappovalmisteiden korvaamisesta bentsoehapolla lihasikojen rehussa ei ollut merkittävää hyötyä. Vaikka valmisteiden korvaaminen bentsoehapolla paransikin useiden ravintoaineiden sulavuutta, eroja ilman happolisäyksiä ruokittuun kontrolliryhmään oli varsin vähän. Vaikutukset virtsan $\mathrm{pH}$-arvoihin olivat vähäisemmät kuin aikaisemmissa tutkimuksissa. Rehun happolisäykset eivät myöskään vaikuttaneet lietelannan ammoniumtypen ja urean määrään. Sikojen kasvua ja rehuhyötysuhdetta paransi ainoastaan nestemäisen muurahaishappotuotteen korvaus bentsoehapolla alkukasvatuksessa, mutta ero ei näkynyt koko kasvatuskauden tuloksissa. Todennäköisesti tässä tutkimuksessa käytetyt rehun bentsoehappolisäykset olivat liian pieniä.

Nestemäisen ja kiinteän happovalmisteen erona oli kiinteässä valmisteessa käytetty piidioksidi eli silika, jonka huokoinen rakenne sitoo tehokkaasti erilaisia molekyylejä. Piidioksidin määrä kiinteää 


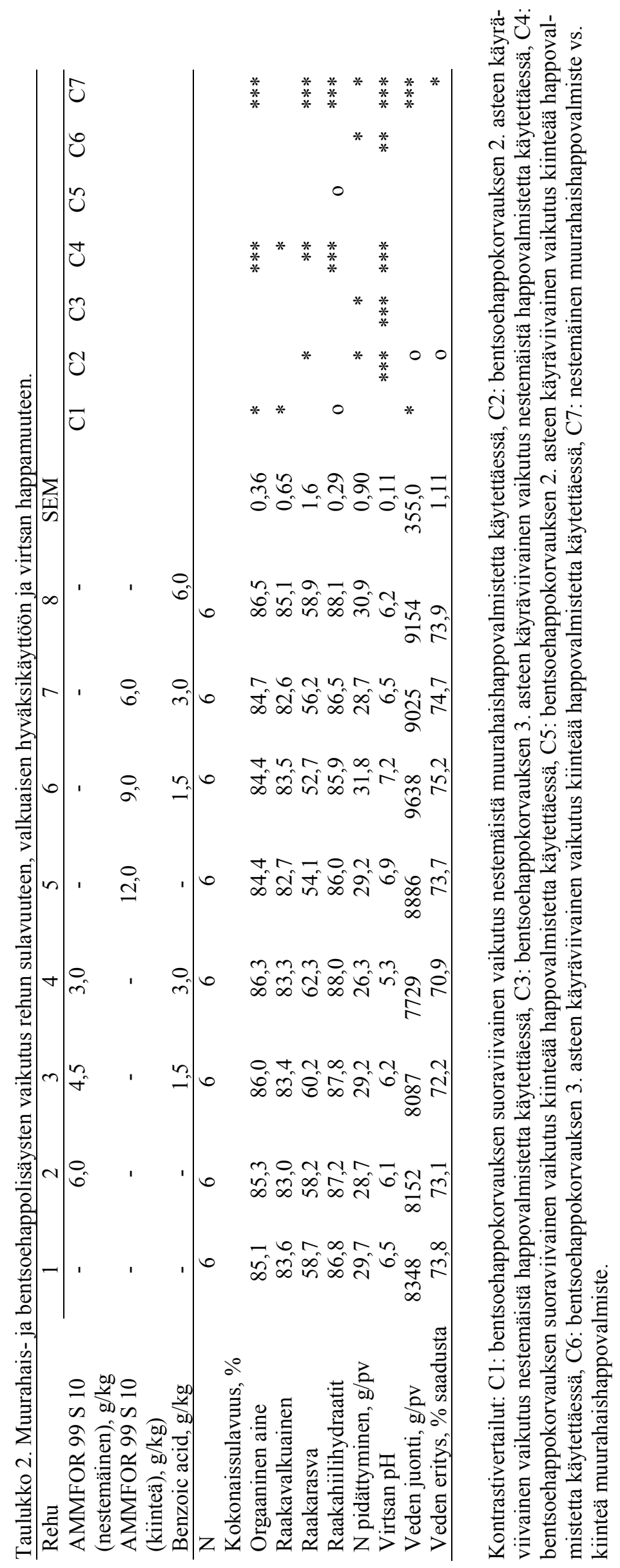




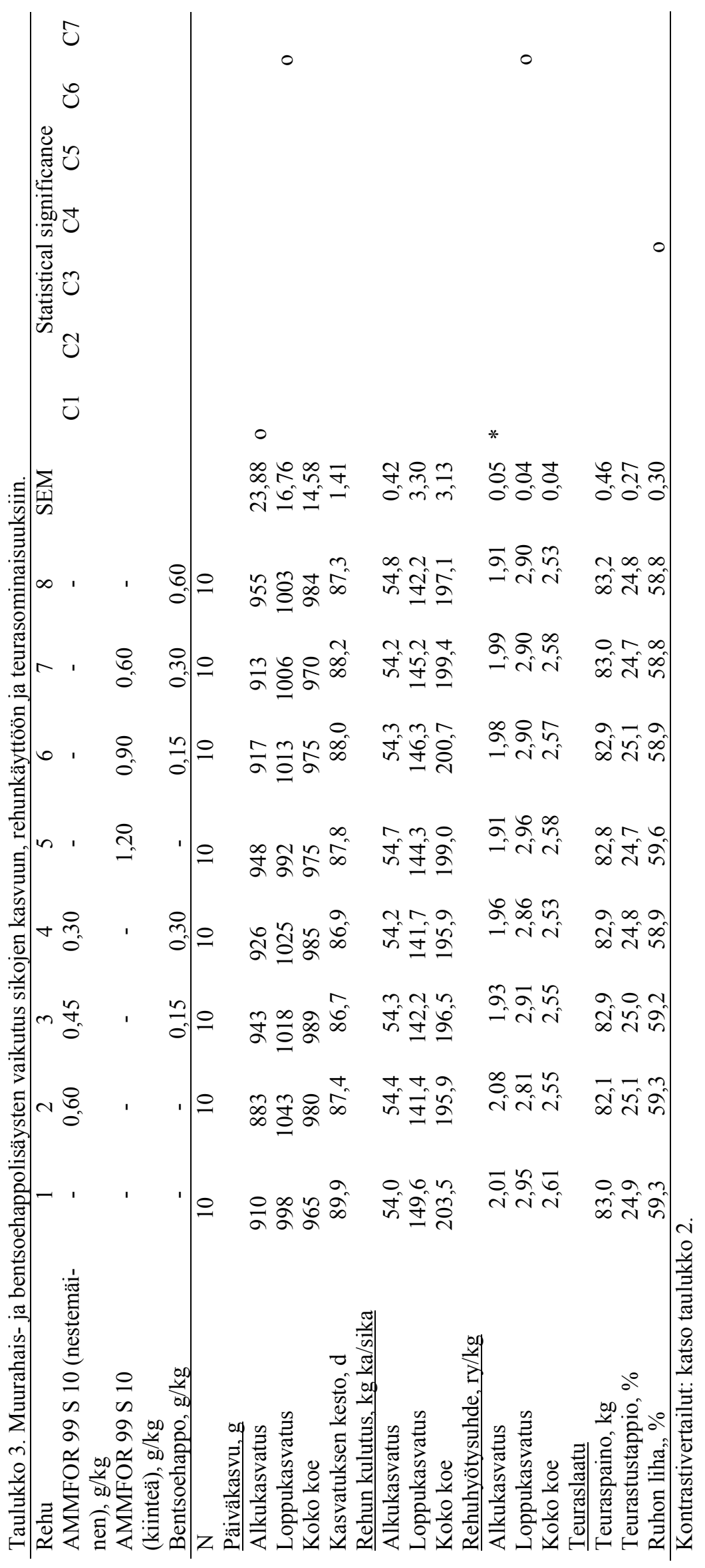


valmistetta sisältäneissä rehuissa oli $2,1-4,1 \mathrm{~g} / \mathrm{kg}$. Tässä tutkimuksessa havaittiin kiinteää happovalmistetta käytettäessä huonompi ravintoaineiden sulavuus, suurempi veden juonti ja virtsan eritys sekä jonkin verran huonompi loppukasvatuksen kasvu ja rehuhyötysuhde kuin nestemäistä valmistetta käytettäessä. Happojen kantaja-aineiden ominaisuuksiin olisi tämän perusteella kiinnitettävä huomiota.

\section{Kirjallisuus}

Knarreborg, A., Miquel, N., Granli, T. \& Jensen, B.B. 2002. Establishment and application of an in vitro methodology to study the effects of organic acids on coliform and lactic acid bacteria in the proximal part of the gastrointestinal tract of piglets. Anim. Feed Sci. Technol. 131-140.

Mellor, S. 2004. Common acidifier has some surprises in store. Feed Mix 12 (1): 28-30.

Mosenthin, R., Sauer W., Ahrens, F., De Lange, C. \& Bornholdt, U. 1992. Effect of dietary supplements of propionic acid, siliceous earth or a combination of these on the energy, protein and amino acid digestibilities and concentrations of microbial metabolites in the digestive tract of growing pigs. Anim. Feed Sci. Technol. 37: 245255.

Mroz, Z., Jongbloed, A.W., Partanen, K., Vreman, K., Kemme, P. \& Kogut, J. 2000. The effects of calsium benzoate in diets with or without organic acids on dietary buffering capacity, apparent digestibility, retention of nutrients, and manure characteristics in swine. J. Anim. Sci. 78: 2622-2632.

MTT 2004. Rehutaulukot ja ruokintasuositukset 2004. Helsinki: Maa- ja elintarviketalouden tutkimuskeskus. MTT:n selvityksiä 86 .

Nordic Committee on Food Analysis 1997. Benzoic acid, sorbic acid and p-hydroxybenzoic acid esters. Liquid chromatographic determination in foods. Nordic Committee on Food Analysis 124, 2nd Ed.

Øverland, M., Granli, T., Kjos, N.P., Fjetland, O., Steien, S.H. \& Stockstad, M. 2000. Effect of dietary formates on growth performance, carcass traits, sensory quality, intestinal microflora, and stomach alterations in growing-finishing pigs. J. Anim. Sci. 78: 1875-1884.

Partanen, K. \& Mroz, Z. 1999. Organic acids for performance enhancement in pig diets. Nutr. Res. Rev.12: $117-145$

Partanen, K. 2001. Organic acids - their efficacy and modes of action in pigs. In: Gut Environment in Pigs. Nottingham University Press, Nottingham. Workshop on 'Feed additives and probiotics as an alternative to antibiotics as growth promoters' in connection with the $8^{\text {th }}$ Symposium on Digestive Physiology in Pigs. $17 \mathrm{p}$.

Partanen, K., Siljander-Rasi, H., Alaviuhkola, T., Suomi, K. \& Fossi, M. 2002. Performance of growingfinishing pigs fed medium- or high-fibre diets supplemented with avilamycin, formic-acid or formic-acid-sorbate blend. Livest. Prod. Sci. 73: 139-152.

Siljander-Rasi, H., Alaviuhkola, T. \& Suomi, K. 1998. Carbadox, formic acid and potato fibre as feed additives for growing pigs. J. Anim. Feed Sci. 7: 205-209.

Van der Peet-Schwering, C.M.C., Verdoes, N. \& Plagge, J.G. 1999. Influence of benzoic acid in the diet on performance and urine $\mathrm{pH}$ of growing-finishing pigs. Research report P 5.8, Research Institute for Pig Husbandry, Rosmalen. 24 p. 